\title{
Anticancer activity of milk fat rich in conjugated linoleic acid against Ehrlich ascites carcinoma cells in female Swiss albino mice
}

\author{
Abdelrahman M. Abd El-Gawad ${ }^{1}$, Diea G. Abo El-Hassan² (D), Ahmed M. Aboul-Enein ${ }^{3}$ (D) Sherein S. Abdelgayed ${ }^{4}$, \\ Salwa A. Aly ${ }^{5}$, Gamal Esmat ${ }^{6}$ iD, Amr A. Mostafa ${ }^{3}$, Mohamed H. Bakr ${ }^{1}$, Rida A. Ali ${ }^{1}$ and Mahmoud A. Ayoub
}

\begin{abstract}
1. Department of Animal Production, Faculty of Agriculture, Cairo University, Giza, Egypt; 2. Department of Medicine and Infectious Diseases, Faculty of Veterinary Medicine, Cairo University, Giza, Egypt; 3. Department of Biochemistry, Faculty of Agriculture, Cairo University, Giza, Egypt; 4. Department of Pathology, Faculty of Veterinary Medicine, Cairo University, Giza, Egypt; 5. Department of Food Hygiene, Faculty of Veterinary Medicine, Cairo University, Giza, Egypt; 6. Department of Hepatogastroenterology and Infectious Diseases, Faculty of Medicine, Cairo University, Giza, Egypt; 7. Department of Clinical and Chemical Pathology, National Cancer Institute, Cairo University, Giza, Egypt.

Corresponding author: Diea G. Abo El-Hassan, e-mail: dieaabo@cu.edu.eg Co-authors: AMA: amabdelgawad2007@gmail.com, AhMA: aboul.enein1@agr.cu.edu.eg,

SSA: sherein.abdelgayed@vet.cu.edu.eg, SAA: salwaaly@cu.edu.eg, GE: gesmat@cu.edu.eg, AAM: dean@agr.cu.edu.eg, MHB: mhmbakr@agr.cu.edu.eg, RAA: rida100@gmail.com, MAA: ayoub.9177@yahoo.com

Received: 21-09-2020, Accepted: 02-02-2021, Published online: 20-03-2021
\end{abstract}

doi: www.doi.org/10.14202/vetworld.2021.696-708 How to cite this article: Abd El-Gawad AM, Abo El-Hassan DG, Aboul-Enein AM, Abdelgayed SS, Aly SA, Esmat G, Mostafa AA, Bakr MH, Ali RA, Ayoub MA (2021) Anticancer activity of milk fat rich in conjugated linoleic acid against Ehrlich ascites carcinoma cells in female Swiss albino mice, Veterinary World, 14(3): 696-708.

\begin{abstract}
Background and Aim: The major conjugated linoleic acid (CLA) isomers have anticancer effect, especially breast cancer cells, inhibits cell growth and induces cell death. Also, CLA has several health benefits in vivo, including antiatherogenesis, antiobesity, and modulation of immune function. The present study aimed to assess the safety and anticancer effects of milk fat CLA against in vivo Ehrlich ascites carcinoma (EAC) in female Swiss albino mice. This was based on acute toxicity study, detection of the tumor growth, life span of EAC bearing hosts, and simultaneous alterations in the hematological, biochemical, and histopathological profiles.
\end{abstract}

Materials and Methods: One hundred and fifty adult female mice were equally divided into five groups. Groups (1-2) were normal controls, and Groups (3-5) were tumor transplanted mice (TTM) inoculated intraperitoneally with EAC cells $\left(2 \times 10^{6} / 0.2 \mathrm{~mL}\right)$. Group (3) was (TTM positive control). Group (4) TTM fed orally on balanced diet supplemented with milk fat CLA (40 mg CLA/kg body weight). Group (5) TTM fed orally on balanced diet supplemented with the same level of CLA 28 days before tumor cells inoculation. Blood samples and specimens from liver and kidney were collected from each group. The effect of milk fat CLA on the growth of tumor, life span of TTM, and simultaneous alterations in the hematological, biochemical, and histopathological profiles were examined.

Results: For CLA treated TTM, significant decrease in tumor weight, ascetic volume, viable Ehrlich cells accompanied with increase in life span were observed. Hematological and biochemical profiles reverted to more or less normal levels and histopathology showed minimal effects.

Conclusion: The present study proved the safety and anticancer efficiency of milk fat CLA and provides a scientific basis for its medicinal use as anticancer attributable to the additive or synergistic effects of its isomers.

Keywords: anticancer activity, conjugated linoleic acid, Ehrlich ascites carcinoma, \% increase in life span, mean survival time, tumor transplanted mice.

\section{Introduction}

Cancer is a category of malignant illnesses that are caused by rapid and uncontrolled formation of abnormal cells which may lump forming tumor or proliferate and imitate abnormal growth at other sites in the body [1]. It is a devastating disease with tremendous negative implications for the personal, healthcare economics, and social levels [2]. Statistically, it is the second major cause of human death after

Copyright: Abd El-Gawad, et al. Open Access. This article is distributed under the terms of the Creative Commons Attribution 4.0 International License (http://creativecommons.org/licenses/ by/4.0/), which permits unrestricted use, distribution, and reproduction in any medium, provided you give appropriate credit to the original author(s) and the source, provide a link to the Creative Commons license, and indicate if changes were made. The Creative Commons Public Domain Dedication waiver (http:// creativecommons.org/publicdomain/zero/1.0/) applies to the data made available in this article, unless otherwise stated. cardiovascular diseases worldwide and is responsible for the deaths of 9.6 million person in 2018 [3]. About 14.1 million cancer cases were diagnosed all over the world in 2012; of these, $52.5 \%$ were in men and $47.5 \%$ in women, and will rise up to 21.7 million by 2030 [4]. It causes about $13 \%$ of all human deaths and according to the American Cancer Society around 7.6 million people die every year from cancer [5]. Several methods are used for the treatment of cancer, such as chemotherapy, radiotherapy, and surgery, the chemotherapy is now considered as an efficient method for treatment. Success of cancer chemotherapy is limited by drugs that have hepatotoxic, nephrotoxic, cardiotoxic, myelosuppressive, multidrug resistance, and other side effects [6] and have become serious medical problems [7]. Recent strategies for cancer prevention depend on the modification of 
lifestyle such as diet, some dietary elements such as conjugated linoleic acid (CLA) can minimize the cancer risk [8]. Therefore, many extensive studies have been devoted recently to search for natural preventive and therapeutic approaches with antitumor, antioxidant, and anti-inflammatory potential can treat various kinds of diseases with less side effects [9]. Milk and its products are considered as important sources of energy and bioactive substances positively associated with human health [10].

Tumor cell line, Ehrlich ascites carcinoma (EAC); is an undifferentiated carcinoma, not have a tumor-specific transplantation antigen, of $100 \%$ malignancy, highly transplantable, very rapid proliferative, and shorter lifespan [11]. It is mostly used to assess the anticancer activity of different agents [12]. This cell line is more sensitive to chemotherapy and used in determining whether the tumor is responding to therapy or not and has similarity with human tumors due to its undifferentiation and rapid growth rate nature [13].

More than 28 different geometrical and positional isomers of linoleic acid conjugated with a double bond system are defined as CLA. Many biological impacts of CLA until now are imputed to two major isomers, namely, cis-9 (c9), trans-11 (t11) and trans10 (t10), cis-12 (c12) constitute about $90 \%$ and $10 \%$ of the total CLA isomers. These isomers are synthesized through a biohydrogenation process by the ruminal bacteria in ruminants, or through bioconversion in mammary gland [14]. The isomers of CLA are active biological molecules, have protective effects against several diseases include atherosclerosis, obesity, osteoporosis, diabetes, cancer, and certain chronic inflammatory afflictions [15]. Anti-carcinogenic effects have been observed in all cancer types, with doses varying between $55 \mathrm{mg}$ and $3.5 \mathrm{~g} \mathrm{CLA/day} \mathrm{[16].} \mathrm{Milk} \mathrm{and} \mathrm{its}$ products represent main source of CLA in the human diet, with nearly $70 \%$ of the daily requirement, and an average intake of $650 \mathrm{mg} /$ day. That intake value is insufficient for achieving beneficial effects on human health. Various technological alternatives in the field of food technology are exploring ways to produce milk and dairy product rich in CLA [17]. Several studies on human nutrition recorded that daily safe requirement of CLA ranged between 3 and $6 \mathrm{~g}$, although some researches mentioned that administration more than $3.4 \mathrm{~g} \mathrm{CLA} /$ day has no beneficial action [18].

Loss of endogenous estrogen production after menopause increases the risk of osteoporosis, cardiovascular diseases, and obesity [19]. Estrogen surrogate therapy effectively reduces and/or prevents these health issues in postmenopausal women [20]. At the same time, exogenous estrogen administration increases the risk of endometrial hyperplasia and breast cancer [21], so there is great interest in natural alternatives to estrogen therapy to avoid postmenopausal hazard on women's health. In postmenopausal women, CLA can inhibit the estrogen receptor (ER) signaling in human endometrial and breast cancer cells [22], acting as an estrogen antagonist through the inhibition of ER alpha (ER $\alpha)$-mediated responses. Bocca et al. [23] reported the strong anticancer action of CLA through the ER signaling inhibition. Amaru et al. [24] concluded that CLA effectively reduces breast cancer risk by inhibiting breast tumor initiation, promotion, and progression. Concerning colorectal cancer, CLA intake succeeded in achieving 30\% reduction and showed significant role in preventing testicular cancer [25].

From this viewpoint, this study was performed to assess the efficacy of milk fat rich in CLA on modulating cancer induced by Ehrlich cells in female Swiss albino mice to enhance a natural tumor therapy. To achieve this goal, several parameters include cell growth inhibition, volume of the ascetic fluid, and mean survival time (MST) of tumor transplanted mice (TTM); in addition, restoration of the hematological, biochemical, and histopathological alterations was studied.

\section{Materials and Methods}

\section{Ethical approval}

This study protocol was approved by the Institutional Animal Care and Use Committee, the Ethics Committee of the Faculty of Veterinary Medicine, Cairo University, Giza, Egypt (Approval No. VetCU10102019088).

\section{Study period and location}

This study was conducted from September 2019 to March 2020 at the Laboratory of Faculty of Agriculture and Veterinary Medicine, Cairo University, Egypt.

\section{Milk fat rich in CLA}

The milk fat rich in CLA was produced from Holstein-Friesian Cows fed on diet contained protected fat, high in unsaturated fatty acids. The CLA percentage of the produced milk fat was $2 \%$ of the fatty acids, while the percentage of CLA in normal cow milk fat ranged between $0.3 \%$ and $0.4 \%$. The cow milk fat rich in CLA was supplemented to the normal balanced diet of mice $(10 \% \mathrm{w} / \mathrm{w})$ and used in feeding the experimental female mice orally at a level of $50 \mathrm{mg}$ (containing $1 \mathrm{mg}$ CLA) per mice, $40 \mathrm{mg}$ CLA/kg body weight (BW), daily.

\section{Experimental animals}

One hundred and fifty adultfemale Swiss albino mice (23-25 g) from the Laboratory Animal Farm in Helwan, Egypt, were housed in plastic mesh cages under strict standard hygienic measures. Female mice selected for this study because EAC is grown and divided in female peritoneal mice and not in male, due this tumor is working on female hormones. The mice were adapted to the laboratory circumstance, 28 days before the experiment onset. The mice were fed on a balanced ration with a good source of water $a d$ libitum, during the acclimatization and experimental 
periods and were exposed to $12 \mathrm{~h}$ of light/ dark cycle during the study.

\section{Acute toxicity study}

The acute oral toxicity investigation of the milk fat enriched CLA was performed in six adult female Swiss albino mice, two mice per treatment dose, at three increasing oral doses 50,100, and $200 \mathrm{mg}$ of the tested milk fat rich in CLA equivalent 40, 80, and $160 \mathrm{mg} \mathrm{CLA} / \mathrm{kg} \mathrm{BW}$, respectively. Following treatment, the mice were observed for $48 \mathrm{~h}$ for any mortality or behavioral changes [26]. Adding different concentrations of milk fat to ration did not produce any mortality in any of the tested dose levels, this encouraged us to perform further assessments using the dose level of $50 \mathrm{mg}$ milk fat (40 mg CLA $/ \mathrm{kg} \mathrm{BW}$ ).

\section{Ascitic tumor induction}

The tumor cell line, EAC, was kindly obtained from the National Cancer Institute, Cairo, Egypt, and propagated intraperitonially (i/p) in Swiss albino mice [27]. Viable tumor cells were detected using Trypan blue stain and counted by hemocytometer. The ascitic fluid was diluted in normal saline to obtain tumor cell suspension of $10 \times 10^{6}$ cells $/ \mathrm{mL}$. From this stock suspension, $0.2 \mathrm{~mL}\left(2 \times 10^{6}\right.$ cells $\left./ \mathrm{mice}\right)$ was inoculated $\mathrm{i} / \mathrm{p}$ to induce ascitic tumor.

\section{Experimental design}

One hundred and fifty adult female Swiss albino mice, about $25 \mathrm{~g}$ each, were equally divided into five groups for anticancer activity evaluations. Group 1 (G1) was kept as normal control; feed on normal balanced ration without tumor cell induction. Group $2(\mathrm{G} 2)$ feed on normal balanced ration supplemented with $50 \mathrm{mg}$ milk fat, $1 \mathrm{mg} \mathrm{CLA} /$ mice, (40 mg CLA/kg BW) by oral route daily without tumor cell inoculation. Group 3 (G3) was positive TTM, inoculated $\mathrm{i} / \mathrm{p}$ by EAC cells $\left(2 \times 10^{6}\right.$ cells/mouse $)$ and fed on normal balanced ration. Group $4(\mathrm{G} 4)$ was inoculated (i/p) by EAC cells $\left(2 \times 10^{6}\right.$ cells/mouse), after $24 \mathrm{~h}$ of inoculation, the mice were treated with $50 \mathrm{mg}$ milk fat, contained $1 \mathrm{mg} \mathrm{CLA} /$ mice (40 mg CLA $/ \mathrm{kg} \mathrm{BW}$ ) by oral route daily. Group 5 (G5) was inoculated (i/p) by EAC cells $\left(2 \times 10^{6}\right.$ cells/mouse), fed with $50 \mathrm{mg}$ milk fat, $1 \mathrm{mg}$ CLA $/$ mice, (40 mg CLA $/ \mathrm{kg} \mathrm{BW}$ ) by oral route daily, 28 days pre inoculation. The oral administration of the treatments was done in the form of paste, representing $10 \%$ of the normal mice ration, daily. After 16 days of tumor induction, ten mice of each group were fasted for $18 \mathrm{~h}$, then anesthetized with diethyl ether and sacrificed. The ascitic fluid was collected and tumor growth was assessed. Percent of tumor growth inhibition was calculated by comparing the tumor cells count in the ascitic fluid of treated groups and the TTM positive control group (G3). Tumor cell growth in peritoneal fluids of the normal control group (G1) was taken as $100 \%$ cell growth to assess the anticancer action of the milk fat CLA.

For histopathological examination, liver and kidneys were harvested. The twenty remaining mice were used for estimating the MST and percent increase in life span (\% ILS). BW of mice, ascitic fluid volume, hematological parameters, red blood cells (RBCs), hemoglobin $(\mathrm{Hb})$, white blood cells (WBCs), differential count, and biochemical parameters was evaluated.

\section{Evaluation of the anticancer activity}

The anticancer activity of milk fat CLA was assessed through definitive parameters include the MST, \% ILS, tumor weight and volume, and restoring of the hematological, biochemical, and histopathological alterations [28].

\section{Life span}

Survival time for TTM and effect of milk fat CLA on tumor growth was observed by MST and \% ILS [29].

\section{MST}

Twenty mice in each group were monitored by 5 weeks. Survival days of each animal from the day of tumor induction were counted, and spontaneous death of mice was considered the endpoint of experiments. The calculation of MST was calculated according to the following equation:

$\operatorname{MST}=\frac{\sum \text { survival time (days) of ach mice in a group }}{\text { Total number of mice }}$

\section{\% ILS}

The effect of milk fat CLA on \% ILS of the animals was calculated by comparing the survival time for treated group with that of control group using the following equation:

$$
\% \text { ILS }=\frac{\text { MST of treated group }-}{\text { MST of control group }} \mid
$$

\section{Tumor weight and tumor volume}

For the determination of tumor weight, ten mice from each group were sacrificed on day 16 of inoculation; the weight was recorded before and after the collection of the ascitic fluid. The difference in weight before and after gives the tumor weight and is expressed in grams. Tumor volume was determined by measuring the ascitic fluid volume using a graduated centrifuge tube [30].

\section{Counting of viable tumor cells}

The ascitic fluid was collected using WBCs diluting pipette and diluted up to 100 times with phosphate-buffered saline. The viable cell counting was performed in 64 squares on Neubauer's chamber using a drop of the prepared dilution. Trypan blue stain $(0.4 \%$ in normal saline) was used to assess the viable cells, viable cells did not take the color of the dyes [30].

\section{Blood sampling}

From the sacrificed mice, $2 \mathrm{~mL}$ of blood were taken per mouse and placed on previously two 
identified microtubes; one with ethylenediamine tetra-acetic acid (EDTA) $10 \%$ as anticoagulant used to measure hematological parameters, and the second one without anticoagulant for separation of serum was used to measure the biochemical parameters [31].

\section{Hematological parameters}

Blood parameters were performed according to Santos et al. [32]. Blood on EDTA was used for RBC counts, estimation of $\mathrm{Hb}$ levels, and $\mathrm{WBC}$ counts. Differential count of WBCs was determined using blood smears stained with Giemsa stain.

\section{Biochemical parameters}

Biomarkers of liver function include serum alanine aminotransferase (ALT), aspartate aminotransferase (AST), and alkaline phosphatase (ALP) activities in addition to serum creatinine, a biochemical analysis for renal function evaluation, were measured and interpreted, according to Tietz [33]. Total protein was measured by means of Biuret reagent and albumin was determined using the modified Bromocresol green, according to Moreira et al. [34]. Globulins were measured by subtracting of albumin from total serum proteins and albumin/globulin $(\mathrm{A} / \mathrm{G})$ ratio was calculated from dividing albumin value on globulin value for each sample. Liver and renal function tests were performed to assess functioning of the liver and kidneys after milk fat CLA administration. Total antioxidant capacity (TAC) was estimated, according to Lalithadevi et al. [35]. The previous biochemical parameters were measured colorimetrically using bio-diagnostic kits.

\section{Histopathological examination}

The treated mice and their controls were anesthetized with diethyl ether and immediately sacrificed, quickly dissected; liver and kidney were removed and fixed in Bouin's fluid. After $24 \mathrm{~h}$, tissues were rinsed 3 times in $70 \%$ ethanol, dehydrated using a graded ethanol series and then embedded in paraffin wax. Paraffin thick slices, $5 \mu \mathrm{m}$, were stained with hematoxylin and eosin and examined under light microscope and photographed using a digital microscope (Olympus BX50, Japan) [36].

\section{Statistical analysis}

The experimental results were expressed as the mean \pm standard error of the mean. The significant difference between the groups was statistically determined by one-way analysis of variance. Data were accepted as statistically significant considering the difference at $\mathrm{p}<0.05$.

\section{Results and Discussion}

Cancer remains a major health problem causing mortality despite novel findings and several new anticancer drugs, its incidence is increasing with an annual rate of $1.2 \%$ [37]. Improvement in cancer treating strategies will result in prolonged survival of patients; however, there is a growing need for additional means of cancer management in both palliative and curative treatments [38].

\section{Acute toxicity of milk fat CLA}

Milk fat CLA was safe at doses as high as $3 \mathrm{mg} / \mathrm{mouse}$ daily ( $160 \mathrm{mg} \mathrm{CLA} / \mathrm{kg} \mathrm{BW}$ ) by oral route. The behavior of the mice was monitored, every $4 \mathrm{~h}$, for a period of $48 \mathrm{~h}$. Milk fat CLA supplemented diet did not induce mortality, behavioral changes, locomotor ataxia, diarrhea, or weight loss in mice during the 48-h observation period. Furthermore, feed and water intake did not differ among the groups of study. Dilzer and Park [15] reported similar findings.

\section{Anticancer activity Effect on MST and \% ILS}

Effect of milk fat CLA on life span, MST and \% ILS, of TTM was investigated (Table-1 and Figure-1). In TTM positive control group (G3), the MST was 16.5 days while it significantly $(\mathrm{p}<0.05)$ increased to 23.5 and 25.2 days in $\mathrm{G} 4$ and G5 fed $1 \mathrm{mg}$ milk fat CLA (40 mg CLA $/ \mathrm{kg} \mathrm{BW.)} \mathrm{daily} 28$ days post- and pre-tumor cells inoculation, respectively. The administration of CLA at a dose of $40 \mathrm{mg} / \mathrm{kg} \mathrm{BW}$, orally significantly $(\mathrm{p}<0.05)$ increased the \% ILS values to $42.4 \%$ and $52.7 \%$ in the treated groups (G4) and (G5), respectively, when compared with the TTM, positive control group (G3). The results of survival analysis revealed

Table-1: Effect of daily oral administration of milk fat rich in CLA on MST and \% ILS in EAC inoculated mice.

\begin{tabular}{|c|c|c|}
\hline Groups & Treatment & MST/days \% ILS \\
\hline$\overline{\text { Grou }}$ & Positive control & 19 \\
\hline & $\begin{array}{l}\text { TTM feed on } 50 \text { mg milk } \\
\text { fat/mouse ( } 1 \mathrm{mg} \text { CLA) daily } \\
\text { post-inoculation. }\end{array}$ & \\
\hline Group 5* & $\begin{array}{l}\text { TTM feed on } 50 \text { mg milk } \\
\text { fat/mouse ( } 1 \text { mg CLA) daily } \\
28 \text { days pre-inoculation. }\end{array}$ & $.35 * 52.73 *$ \\
\hline
\end{tabular}

The values expressed as mean $\pm \mathrm{SE}, \mathrm{TTM}=$ Tumor transplanted mice with EAC cells, *Significant at $(p<0.05)$ as compared with positive control group (Group 3, TTM). $\mathrm{CLA}=$ Conjugated linoleic acid, MST=Mean survival time, $\mathrm{EAC}=$ Ehrlich ascites carcinoma, \% ILS $=$ Percent increase in life span, TTM=Tumor transplanted mice, MST=Mean survival time

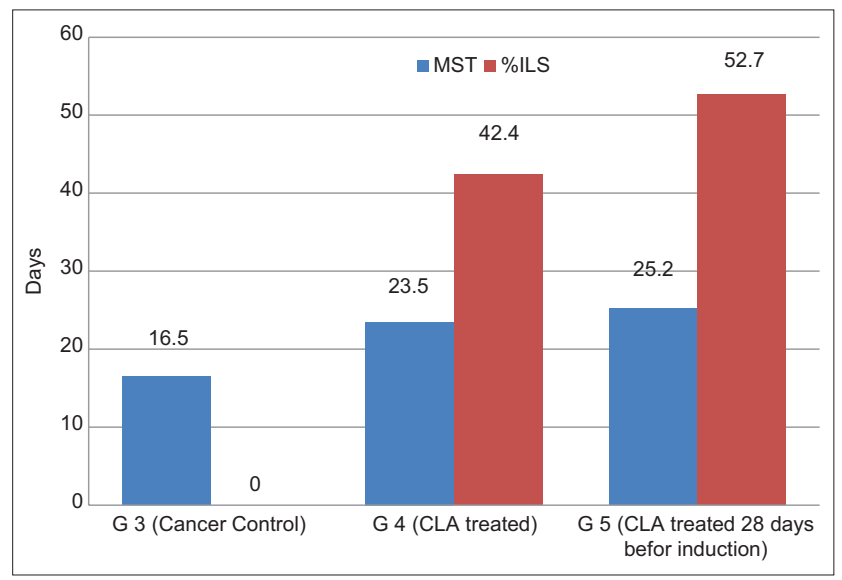

Figure-1: Mean survival time/day and percent increase in life span of tumor transplanted mice treated with milk fat rich in conjugated linoleic acid. 
that MST and ILS\% were significantly increased in milk fat CLA treated mice (Groups 4 and 5).

\section{Effect on tumor weight and tumor volume}

Milk fat CLA supplement leads to significant $(p<0.05)$ reduction in the weight and volume of tumor in TTM treated groups (Table-2 and Figure-2a). Tumor weight of TTM control group (G3) was found to be $5.8 \mathrm{~g}$ and that of milk fat CLA treated mice G4 and G5 at a dose of $40 \mathrm{mg}$ CLA/ $/ \mathrm{kg} \mathrm{BW}$, was 3.7 and $3.1 \mathrm{~g}$ with weight growth inhibition 36.2 and $46.6 \%$, respectively. The ascitic fluid volume of the TTM control group was $7 \mathrm{~mL}$, and it was significantly $(\mathrm{p}<0.05)$ reduced to 4.3 and $3.2 \mathrm{~mL}$ with a volume inhibition 37.1 and $54.3 \%$ in treated mice groups G4 and G5, respectively.

\section{Effect on viable cell count (cells $\times 0^{6} / \mathrm{mL}$ )}

As shown in Table-3 and Figure-2b, the mean viable cell count of TTM positive control group (G3) was $330 \pm 0.2$ and significantly $(p<0.05)$ decreased to $216 \pm 1$ and $152 \pm 9$ in treated mice G4 and G5, at dose of $40 \mathrm{mg} / \mathrm{kg} \mathrm{BW}$, respectively. The viable cell reduction in both treated groups was $65.5 \%$ and $46.1 \%$ while tumor cell inhibition was $34.5 \%$ and $53.9 \%$, respectively. The antitumor nature of milk fat CLA was evidenced by the significant inhibition in tumor weight and ascitic volume and the significant reduction in viable tumor cell count, in milk fat CLA treated mice as compared to the TTM positive control group (G3).

EAC is one of the commonly used experimental breast tumor that derived from spontaneous mouse adenocarcinoma that characterized by ascites [28]. In cancer, the increased volume of ascitic fluid indicates tumor growth; hence, decrease in ascitic fluid volume and arresting the tumor growth increase the life span of animals [39]. The obtained results in vivo supported this hypothesis as $\mathrm{i} / \mathrm{p}$ inoculation of EAC cells into mice significantly increased the number of life EAC cells and subsequent ascites. Oral administration of $50 \mathrm{mg}$ milk fat rich in CLA per mice (40 mg CLA $/ \mathrm{kg}$ live BW) to TTM treated groups (G4 and G5) significantly $(p<0.05)$ enhanced the MST and increased the life span of the inducted mice (Figure-1), significantly decreased tumor weight and volume (Figure-2a), number and percent of life EAC cells (Figure-2b) as well as WBCs count (Figure-3c), as compared to the TTM positive control (G3). Reddy et al. [38] reported that a $25 \%$ increase in the life span of ascites bearing animals is a significant indication of drug activity. The observations in the present experiment indicated the effectiveness of milk fat CLA on EAC cells and its role in the delay of cell division, thereby suggesting the reduction in EAC volume and increased survival time in mice. This meets the steadfast criteria, prolongation of life span and decrease in $\mathrm{WBC}$, for judging the potency of any anticancer agent [30,38,39].

\section{Hematological parameters}

The results in Table-4, Figures- 3 and 4 showed that; on the $16^{\text {th }}$ day after tumor cells inoculation, the hematological parameters of TTM positive control group $(\mathrm{G} 3)$ were significantly $(\mathrm{p}<0.05)$ altered, relative to the normal group (G1). The RBCs count (Figure-3a) and $\mathrm{Hb}$ (Figure-3b) were significantly $(\mathrm{p}<0.05)$ decreased to $2.2 \times 10^{6}$ cells $/ \mathrm{mm}^{3}$ and $8.3 \mathrm{~g} \%$, respectively, while WBCs count (Figure-3c) was significantly $(\mathrm{p}<0.05)$ increased to $14.2 \times 10^{3}$ cells $/ \mathrm{mm}^{3}$.

Table-2: Effect of daily oral administration of milk fat rich in CLA on tumor growth in EAC inoculated mice.

\begin{tabular}{|c|c|c|c|c|c|c|}
\hline \multirow[t]{2}{*}{ Groups } & \multirow[t]{2}{*}{ Treatment } & \multirow{2}{*}{$\begin{array}{l}\text { Mean body } \\
\text { weights }\end{array}$} & \multicolumn{4}{|c|}{ Tumor growth } \\
\hline & & & W (g) & WI (\%) & $\mathbf{v}(\mathbf{m L})$ & VI (\%) \\
\hline Group 1 & $\begin{array}{l}\text { Normal control (mice feed on balanced ration } \\
\text { without inoculation) }\end{array}$ & $24.9 \pm 0.3$ & - & - & - & - \\
\hline Group 2 & $\begin{array}{l}\text { Mice feed on } 50 \mathrm{mg} \text { milk fat/mouse ( } 1 \mathrm{mg} \text { CLA) } \\
\text { daily for } 28 \text { days without inoculation }\end{array}$ & $25.0 \pm 0.3$ & - & - & - & - \\
\hline Group 3 & Positive control (TTM) feed on balanced ration & $30.7 \pm 0.1$ & $5.8 \pm 0.1 *$ & 100.0 & $7.0 \pm 0.4 *$ & 100.0 \\
\hline Group 4 & $\begin{array}{l}\text { TTM feed on } 50 \mathrm{mg} \text { milk fat/mouse ( } 1 \mathrm{mg} \mathrm{CLA}) \\
\text { daily post-inoculation. }\end{array}$ & $28.6 \pm 0.1$ & $3.7 \pm 0.2 * *$ & $36.2 * *$ & $4.4 \pm 0.2 * *$ & $37.1 * *$ \\
\hline Group 5 & $\begin{array}{l}\text { TTM feed on } 50 \mathrm{mg} \text { milk fat/mouse ( } 1 \mathrm{mg} \mathrm{CLA}) \\
\text { daily } 28 \text { days pre-inoculation. }\end{array}$ & $28.1 \pm 0.1$ & $3.1 \pm 0.2 * *$ & $46.6 * *$ & $3.2 \pm 0.1^{* *}$ & $54.3 * *$ \\
\hline
\end{tabular}

The values expressed as mean $\pm \mathrm{SE}, \mathrm{W}=$ Weight, $\mathrm{WI}=$ Weight inhibition, $\mathrm{V}=$ Volume, $\mathrm{VI}=$ Volume inhibition, *Significant at $\mathrm{P}<0.05$ as compared with normal control group (Group 1), **Significant at $\mathrm{P}<0.05$ as compared with EAC group (Group 3). CLA=Conjugated linoleic acid, EAC=Ehrlich ascites carcinoma, TTM=Tumor transplanted mice

Table-3: Effect of daily oral administration of milk fat rich in CLA on viable cell count.

\begin{tabular}{lccc}
\hline Groups & \multicolumn{2}{c}{ Viable cell count $\left(\times \mathbf{1 0}^{6}\right)$} \\
\cline { 2 - 4 } & $\begin{array}{c}\text { Viable cell count (Number } \\
\text { of tumor cells) }\end{array}$ & $\begin{array}{c}\text { Viable cell count } \\
\text { \% (Tumor cell growth \%) }\end{array}$ & $\begin{array}{c}\text { Viable cells inhibition (I\%) (Tumor } \\
\text { cells inhibition \%) }\end{array}$ \\
\hline Group 3 & $330 \pm 2$ & 100.0 & 100.0 \\
Group 4 & $216 \pm 1^{*}$ & $65.5^{*}$ & $34.5^{*}$ \\
Group 5 & $152 \pm 9^{*}$ & $46.1^{*}$ & $53.9^{*}$
\end{tabular}

The values expressed as mean \pm SE. *Significant at $(p<0.05)$ as compared with positive control group (Group 3 , TTM). $\mathrm{CLA}=$ Conjugated linoleic acid, TTM=Tumor transplanted mice 


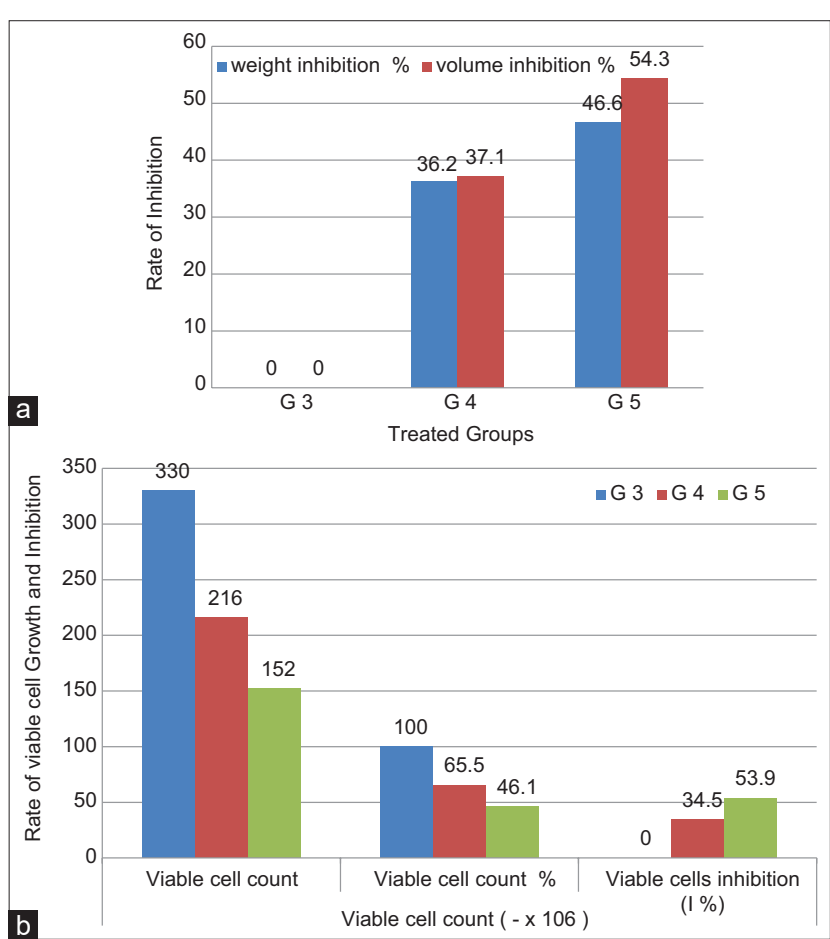

Figure-2: Tumor growth rate in tumor transplanted mice treated with milk fat rich in conjugated linoleic acid: (a) Weight and volume inhibition percent, (b) viable cell count and percentage of viable cell inhibition.

In addition, the differential count of WBCs showed significant decrease $(31.1 \%)$ in the percentage of lymphocytes (Figure-4a) while the percentage of neutrophils (Figure-4b) and monocytes (Figure-4c) significantly increased $(55.0 \%$ and $2.0 \%)$, respectively. Significantly $(\mathrm{p}<0.05)$ restoring all the hematological alterations, in the treated groups (G4) and (G5) to near normal values, after oral administration of milk fat CLA at the same time period.

Anemia in TTM or during chemotherapy protocols, mainly due to reduction in RBC or hemoglobin percentage as a result of iron deficiency or myelosuppression [40]. Restoration of hemoglobin content and maintenance for the nearly normal values of RBCs and WBCs count of the treated mice groups (G4 and G5) after 16 days of tumor induction clearly indicates that milk fat CLA was able to reverse the alteration in the hematological parameters consequent to tumor inoculation and possesses a protective action on the hemopoietic system, suggesting its anticancer nature without inducing myelotoxicity.

Lymphocyte count significantly increased in the TTM treated groups (G4 and G5) after administration of milk fat CLA demonstrating that, CLA has the potentials of improving the cellular immune system and its effectiveness in treatment of disease conditions caused by lymphocytopenia in mammals [41].

\section{Biochemical parameters}

\section{Liver function}

In respect to liver functions, transaminases and ALP levels were determined in the sera of the
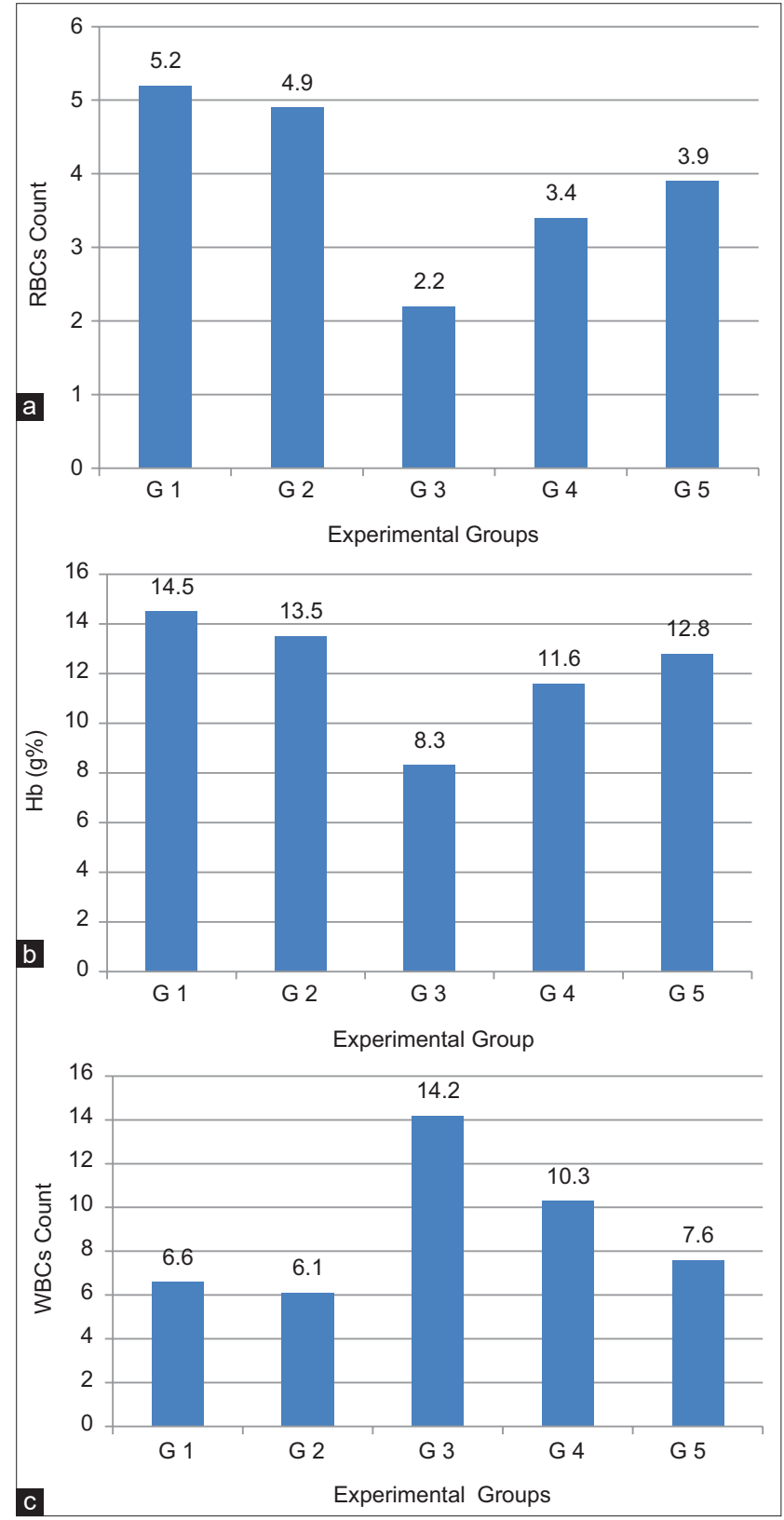

Figure-3: Effect of daily oral administration of milk fat rich in conjugated linoleic acid on: (a) Red blood cells count, (b) hemoglobin content, and (c) white blood cells count.

tested mice groups. Results, as shown in Table- 5 and Figure-5, proved that supplementation of diet with milk fat CLA with level of $40 \mathrm{mg}$ CLA/ $\mathrm{kg}$ live BW did not affect transaminase, ALT and AST enzyme, activities in the sera of the tested normal animal group $(\mathrm{G} 2)$. Induction of cancer into animals (G3), severely affect transaminases activity in its sera. The activities of both ALT (Figure-5a) and AST (Figure-5b) were significantly $(\mathrm{p}<0.05)$ elevated from 17.87 to $22.78 \mathrm{IU} / \mathrm{L}$ and from 15.89 to $25.61 \mathrm{IU} / \mathrm{L}$, respectively. When TTM fed on diet supplemented with $40 \mathrm{mg}$ CLA $/ \mathrm{kg}$ live BW (Group G4), the elevation in transaminase activities significantly $(\mathrm{p}<0.05)$ lowered than that in TTM (G3). The enzyme activity levels reached nearly the normal levels as compared to Groups G1 and G2 but the levels were slightly still high $(19.40 \pm 1.3$ and 
Table-4: Effect of daily oral administration of milk fat rich in CLA on hematological parameters in EAC inoculated Mice.

\begin{tabular}{|c|c|c|c|c|c|c|}
\hline Groups & $\begin{array}{c}\text { RBC count } \\
\left(10^{6} \mathrm{cells} / \mathrm{mm}^{3}\right)\end{array}$ & Hb (g \%) & $\begin{array}{c}\text { WBC count } \\
\left(10^{3} \mathrm{cells} / \mathrm{mm}^{3}\right)\end{array}$ & $\begin{array}{c}\text { Lymphocytes } \\
(\%)\end{array}$ & $\begin{array}{c}\text { Neutrophils } \\
(\%)\end{array}$ & $\begin{array}{c}\text { Monocytes } \\
(\%)\end{array}$ \\
\hline Group 1 & $5.2 \pm 0.1$ & $14.5 \pm 0.7$ & $6.6 \pm 0.1$ & $69 \pm 0.9$ & $25.5 \pm 0.8$ & $1 \pm 0.3$ \\
\hline Group 2 & $4.9 \pm 0.1$ & $13.5 \pm 0.3$ & $6.1 \pm 0.1$ & $74 \pm 0.2$ & $26.2 \pm 0.4$ & $1 \pm 0.5$ \\
\hline Group 3 & $2.2 \pm 0.1 *$ & $8.3 \pm 0.2 *$ & $14.2 \pm 0.2 *$ & $31.1 \pm 1.0 *$ & $55 \pm 1.9 *$ & $2 \pm 0.6 *$ \\
\hline Group 4 & $3.4 \pm 0.1 * *$ & $11.6 \pm 0.2 * *$ & $10.3 \pm 0.20 * *$ & $48.9 \pm 2.1 * *$ & $38.2 \pm 0.9 * *$ & $1.2 \pm 0.3 * *$ \\
\hline Group 5 & $3.9 \pm 0.2 * *$ & $12.8 \pm 0.3^{* *}$ & $7.6 \pm 0.15^{* *}$ & $59.9 \pm 1.5^{* *}$ & $27.1 \pm 0.7 * *$ & $1.1 \pm 0.1 * *$ \\
\hline
\end{tabular}

The values expressed as mean $\pm \mathrm{SE}$, *Significant at $\mathrm{P}<0.05$ as compared with normal control group (Group 1 ),

**Significant at $\mathrm{P}<0.05$ as compared with EAC group (Group 3 ). SE=Standard error, CLA=Conjugated linoleic acid, $\mathrm{EAC}=$ Ehrlich ascites carcinoma

Table-5: Activities of ALT, AST, ALP, Creatinine, and TAC in EAC inoculated mice sera after oral administration of milk fat rich in CLA.

\begin{tabular}{|c|c|c|c|c|c|c|}
\hline Groups & Treatment & ALT (IU/L) & AST (IU/L) & ALP (IU/L) & Creatinine (mg/DL) & $\operatorname{TAC}(\mathrm{mm} / \mathrm{L})$ \\
\hline Group 1 & $\begin{array}{l}\text { Normal mice fed on balanced } \\
\text { diet without EAC induction. }\end{array}$ & $17.87 \pm 1.4$ & $15.89 \pm 1.1$ & $37.38 \pm 5$ & $1.46 \pm 0.01$ & $1.55 \pm 0.11$ \\
\hline Group 2 & $\begin{array}{l}\text { Normal mice fed on balanced } \\
\text { diet supplemented with milk } \\
\text { fat CLA without EAC induction }\end{array}$ & $18.12 \pm 1.6$ & $16.11 \pm 1.2$ & $37.51 \pm 4$ & $1.49 \pm 0.02$ & $1.82 \pm 0.14^{*}$ \\
\hline Group 3 & $\begin{array}{l}\text { TTM fed on normal } \\
\text { diet (Cancer control) }\end{array}$ & $22.78 \pm 1.5^{*}$ & $25.61 \pm 2 *$ & $137.92 \pm 9 *$ & $3.80 \pm 0.08^{*}$ & $1.04 \pm 0.05$ \\
\hline Group 4 & $\begin{array}{l}\text { TTM fed on balanced diet } \\
\text { supplemented with } 40 \mathrm{mg} / \mathrm{kg} \\
\text { milk fat CLA }\end{array}$ & $19.40 \pm 1.3 * *$ & $16.20 \pm 1 * *$ & $56.79 \pm 4 * *$ & $2.24 \pm 0.02 * *$ & $1.48 \pm 0.12 * *$ \\
\hline
\end{tabular}

The values expressed as mean $\pm \mathrm{SE}$, *Significant at $\mathrm{P}<0.05$ as compared with normal control group (Group 1 ), **Significant at $\mathrm{P}<0.05$ as compared with TTM control group (Group 3). ALT=Aminotransferase, AST=Aspartate aminotransferase, $\mathrm{ALP}=$ Alkaline phosphatase, $\mathrm{TAC}=$ Total antioxidant capacity, $C L A=$ Conjugated linoleic acid, TTM=Tumor transplanted mice, EAC $=$ Ehrlich ascites carcinoma

16.20, respectively). This means that CLA is highly effective for redressing disturbances in serum transaminases by cancer transplantation in experimental mice. The results of ALP activity in sera of the previous examined groups, showed similar trend as transaminases (Figure-5c). The levels were significantly $(p<0.05)$ elevated from 37.38 to 137.92 IU/L by induction of tumor cells (G3) then, significantly reduced to $56.79 \mathrm{IU} / \mathrm{L}$ when the diet was supplement with $40 \mathrm{mg}$ CLA $/ \mathrm{kg}$ live BW (G4). However, the addition of milk fat CLA into the diet as supplement at a level of $40 \mathrm{mg}$ $\mathrm{CLA} / \mathrm{kg} \mathrm{BW}$ greatly improved the negative effect of the cancer induction in animals.

\section{Kidney function}

Concerning the creatinine contents in the sera of the examined animal groups (Figure-5d), similar changes were detected by administration milk fat CLA either in normal mice groups or tumor transplanted ones. Creatinine level did not change in the sera of animals which were fed on diet containing $40 \mathrm{mg}$ $\mathrm{CLA} / \mathrm{kg}$ BW (G2) as compared to animals fed on a normal diet $(\mathrm{G} 1)$ while, the level was significantly $(p<0.05)$ elevated from 1.46 to $3.80 \mathrm{mg} / \mathrm{DL}$ by cancer cell transplantation (G3). The elevation in creatinine levels by cancer induction was significantly reduced to $2.24 \mathrm{mg} / \mathrm{DL}$ (Table-5 and Figure-5d) after feeding the TTM on a diet rich in CLA at a dose of $40 \mathrm{mg} \mathrm{CLA} / \mathrm{kg}$ BW (G4). Therefore, diet supplemented with milk fat CLA at a level of $40 \mathrm{mg}$ CLA $/ \mathrm{kg}$ BW significantly improved the dangerous elevation in creatinine levels and can, in turn, protect the kidney from the negative effects of cancer.

\section{Serum proteins}

Data in Table-6 show the serum protein (total and $\mathrm{A} / \mathrm{G}$ ) results of normal and TTM fed on a normal diet and that supplemented with milk fat CLA. Total proteins (Figure-5a) and albumin (Figure-5b) are significantly $(\mathrm{p}<0.05)$ decreased, from 5.39 to $3.92 \mathrm{~g} / \mathrm{DL}$ and from 2.85 to $1.41 \mathrm{~g} / \mathrm{DL}$, respectively, by cancer induction but the levels were significantly re-increased, to $5.15 \mathrm{~g} / \mathrm{DL}$ and $2.64 \mathrm{~g} / \mathrm{DL}$, respectively, by daily oral administration of $40 \mathrm{mg}$ CLA/ kg BW (G4). Globulin, however, showed opposite behavior which was increased by cancer transplantation then reduced by milk fat CLA supplementation. $\mathrm{A} / \mathrm{G}$ ratio was decreased as compared to normal mice.

Liver being the immediate target organ affected by fast-growing EAC cells, uncontrolled gene expression. Patra et al. [39] stressed that serum enzymes are consider early indicators of neoplasia and as auxiliary for recognizing the extent of cancer progression or regression. Tumor in human or animals is known to affect the liver functions. Significant elevation in AST, ALT, and ALP activity levels in the sera of TTM indicate damage in liver cells, while elevation in creatinine level is due to kidney dysfunction [42]. Halaby et al. [43] stated that several investigators also reported liver damage and disturbances in hepatic cell metabolism in TTM with EAC cells, and the serum level of liver enzymes is considered as reliable indices of 


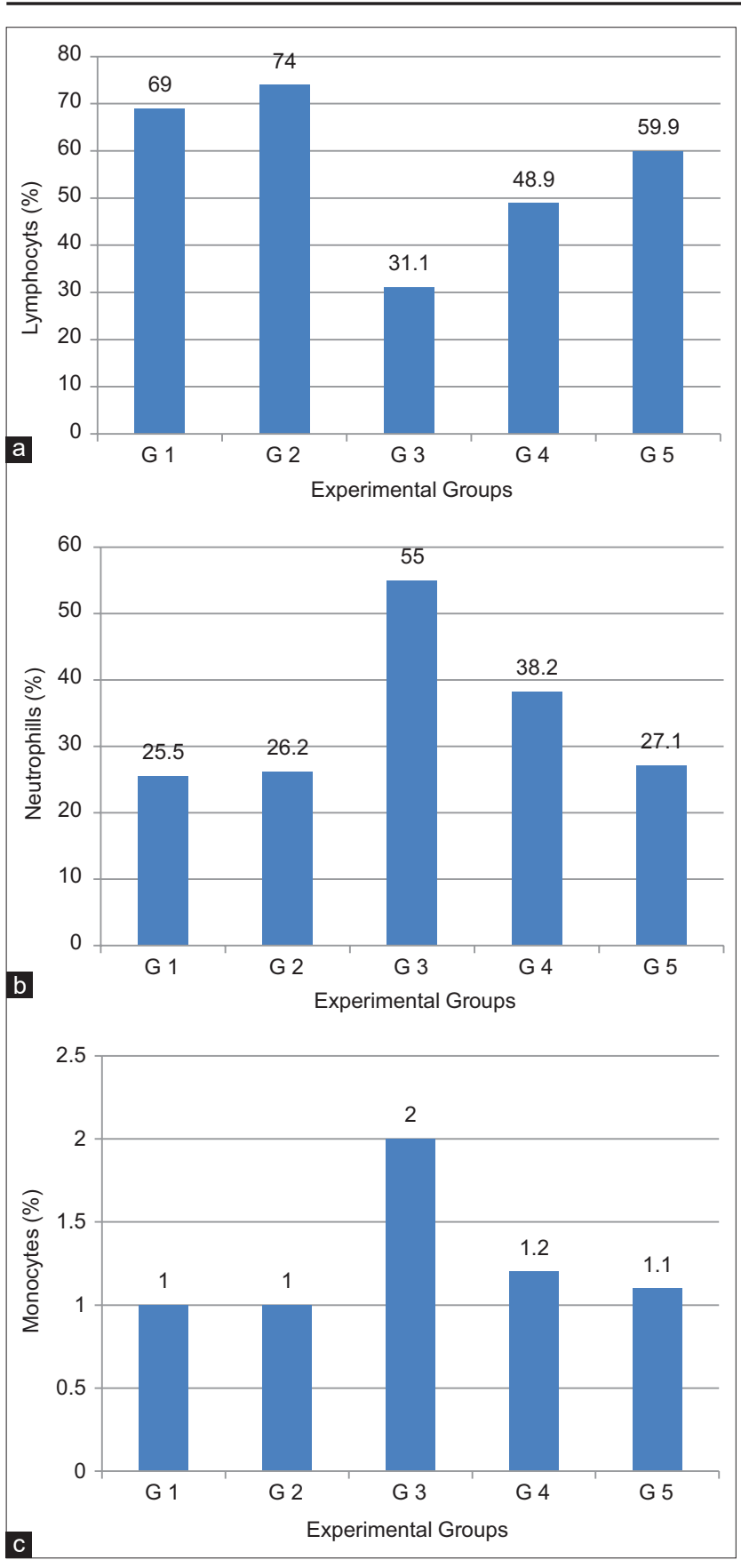

Figure-4: Effect of daily oral administration of milk fat rich in conjugated linoleic acid on: (a) Lymphocytes, (b) neutrophils, and (c) monocytes \%.

Table-6: Effect of daily oral administration of milk fat rich in CLA on serum proteins $(\mathrm{g} / \mathrm{DL})$ in EAC inoculated mice.

\begin{tabular}{lcccc}
\hline Groups & Total & Albumin & Globulin & A/G ratio \\
\hline Group 1 & $5.39 \pm 0.1$ & $2.85 \pm 0.1$ & $2.51 \pm 0.03$ & $1.12 \pm 0.05$ \\
Group 2 & $5.74 \pm 0.2$ & $3.01 \pm 0.2$ & $2.73 \pm 0.02$ & $1.10 \pm 0.04$ \\
Group 3 & $3.92 \pm 0.1 *$ & $1.41 \pm 0.2 *$ & $2.54 \pm 0.04$ & $0.56 \pm 0.04 *$ \\
Group 4 & $5.17 \pm 0.1$ & $2.64 \pm 0.2 * * 2.52 \pm 0.02 * *$ & $1.04 \pm 0.01 * *$ \\
\hline & The values expressed as mean $\pm S E, *$ Significant \\
at ( $\mathrm{p}<0.05$ ) as compared with normal control \\
group (Group 1), **Significant at ( $<<0.05$ ) as compared \\
with TTM control group (Group 3). CLA=Conjugated \\
linoleic acid, TM=Tumor transplanted mice, EAC=Ehrlich \\
ascites carcinoma
\end{tabular}

hepatotoxicity. Nearly similar findings were reported by Habib et al. [44] who reported that damage effects of EAC on the renal tissue were reflected by a significant increase in serum creatinine. Such biochemical change is the outcome of nephropathy.

The treatment of cancer with natural anticancer agents can inhibit the bad effect in liver [40]. Our results showed that diet supplemented with milk fat CLA greatly improved the disturbances in liver enzymes by tumor transplantation. In a similar study on TTM with EAC, Al Abdan [45] reported that administration of $\alpha$-lipoic acid (LA) regulated liver enzymes ALT, AST, ALP, and indicated the efficiency of LA as cancer inhibitor and its therapeutic influence. Lalithadevi et al. [35] declared that reduction of hepatic enzymes level in serum is one of the indications of the antitumor potential and treatment against tumor cells; they attributed the hepatoprotective effect of CLA to its isomers that induce cytotoxicity in hepatocytes or through its antioxidant property. The disturbance in liver and kidney function by tumor transplantation will consequently affect protein levels in blood of the experimental animals [46]. The significant decrease in total serum proteins and albumin, in the present study agrees with the results obtained by Saad et al. [46] who also mentioned that in mice treated with EAC cells, total proteins, albumin percentages, and $\mathrm{A} / \mathrm{G}$ ratios were decreased as compared to normal mice. In our previous study, the results confirmed clear anticancer activity for milk rich in CLA in both tumor cell lines (in vitro) and TTM (in vivo). The study came to the conclusion that milk rich in CLA enhance cancer cells to enter the apoptotic pathway [47]. As shown in Table-6 and Figure-6, oral administration of supplemented diet with milk fat CLA to TTM, led to great disappearance for abnormalities in the biochemical parameters and returned them nearly to the normal levels. The reduced level of these biochemical parameters in serum is one of the indications of the antitumor potential and treatment against tumor cells [48].

The present work showed that cancer induction into mice gave changes (decreases) in the TAC, which was modified by milk fat CLA administration (Table-5). In this concern, we can suggest that CLA has a potential therapeutic complement in the cure or prevention of different disturbances associated with cancer due to imbalance in the cellular oxidoreductive status. This suggestion was previously confirmed by Al Abdan [45] who also suggested that supplementation with natural compounds that are thought to influence liver function can improve liver dysfunction in TTM, in addition to its oncostatic effect. The natural compounds as polyunsaturated fatty acids (PUFAs), including CLA, exhibit antioxidant activity and have a major role in cancer treatment. It is well documented that the higher the intracellular concentrations of lipid peroxides, the lower the mitotic rate and vice versa, tumor cells are resistant to lipid peroxidation in comparison with normal cells [35]. This observation is in tune with the fact that cancer cells have lower 


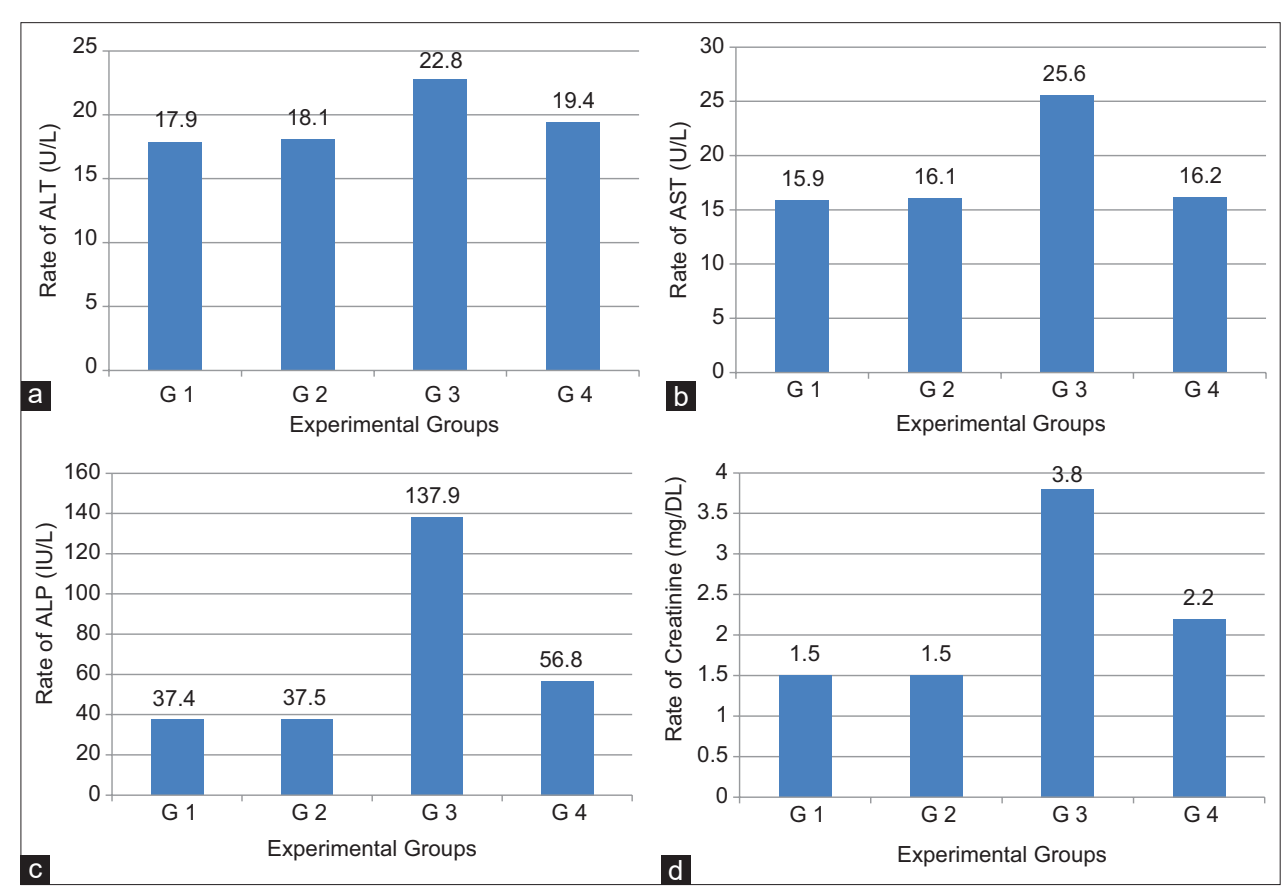

Figure-5: (a-d) Liver and kidney function tests in sera of Ehrlich ascites carcinoma inoculated mice after oral administration of milk fat rich in conjugated linoleic acid.
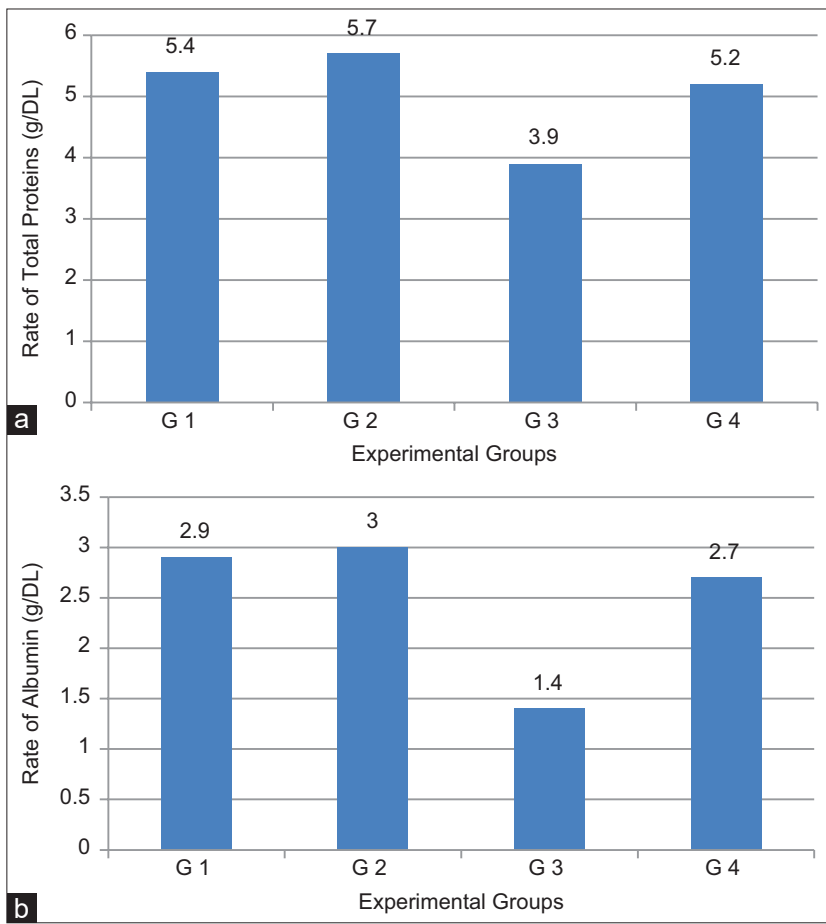

Figure-6: (a) Total proteins and (b) albumin in sera of Ehrlich ascites carcinoma inoculated mice after oral administration of milk fat rich in conjugated linoleic acid.

microsomal phospholipid content and low content of PUFAs [49]. Hence, accumulation of toxic lipid peroxides only in tumor but not in normal cells may be the cause of CLA tumoricidal action. Coadministration of these bioactive CLA isomers in conjunction with conventional anticancer drugs can induce remission of other tumors in humans. Thus, even drug-resistant cancers could be effectively treated using this bioactive lipid-based therapeutic approach [50].

\section{Histopathological results}

Liver

Both control negative mice group fed on a normal diet (G1) and the mice group fed on normal diet supplemented with milk fat CLA (G2) showed normal structure of liver, formed from polygonal lobules with indistinct outlines. Hepatocytes were polyhedral in shape, had vesicular spherical nuclei with prominent nucleoli and eosinophilic cytoplasm. Hepatocytes were arranged in cords that radiated out from the center of each lobule where the central vein situated. Between the hepatic cords hepatic sinusoids are localized and contained fine arrangement of Kupffer cells (Figure-7a and b), these findings were approved by Abou Zaid et al. [51]. EAC bearing mice positive group, (G3) revealed massive pathological alterations distributed throughout the hepatic tissue. Liver showed enlarged and congested central vein, coagulative degeneration was also obvious in the hepatocytes. Kupffer cells were abundant more than normal. Infiltration of cancer cells mixed with leukocytes as a sign of tumor metastasis in liver tissue was reported (Figure-7c and d). These findings were in agreement with Bhattacharyya et al. [52]. Examination of liver sections obtained from EAC mice treated with milk fat CLA, $40 \mathrm{mg} \mathrm{CLA} / \mathrm{kg} \mathrm{BW}$, (G4) revealed reasonable ameliorations to a great extent, but the central vein was still mildly congested and enlarged (Figure-7e). Hepatotoxicity induced by EAC cells were nullified by the preventive effects of milk fat CLA supplementation in mice treated with milk fat CLA 28 days before experimental EAC inoculation (G5) and revealed normal histological lesions nearly similar to those of the control negative group (Figure-7f). 
Kidney

Both control negative mice group fed on a normal diet (G1) and mice group fed on normal diet supplemented with milk fat CLA (G2) were composed of two main regions; the renal cortex and medulla which possess normal histological features. The renal cortex is enclosed by numerous renal corpuscles, each made up of glomeruli and the Bowman's capsule. There is a characteristic normal space between the glomeruli and Bowman's capsule to allow renal filtration. Proximal and distal convoluted tubules surround the renal corpuscles; these tubules have inner wide luminal space lined externally with cuboidal epithelium (Figure-8a and b). Positive group, EAC bearing mice (G3) revealed marked damage of renal tissues which are represented in degenerated renal tubules and glomerular atrophy. Proteinous casts in the lumen of the renal tubules were also observed. Infiltration of tumor cells mixed with leukocytes as a sign of tumor metastasis in kidneys tissue was clearly denoted, (Figure-8c and d); this result is in concomitance with Abd El-Wahab and Fouda [53]. Examination of kidneys sections obtained from EAC mice treated with milk fat CLA, $40 \mathrm{mg} \mathrm{CLA} / \mathrm{kg}$ BW (G4) revealed reasonable ameliorations to a great extent, with somewhat little degeneration in renal tubules (Figure-8e). Nephrotoxicity induced by EAC cells was nullified by the preventive effects of milk fat CLA supplementation in mice

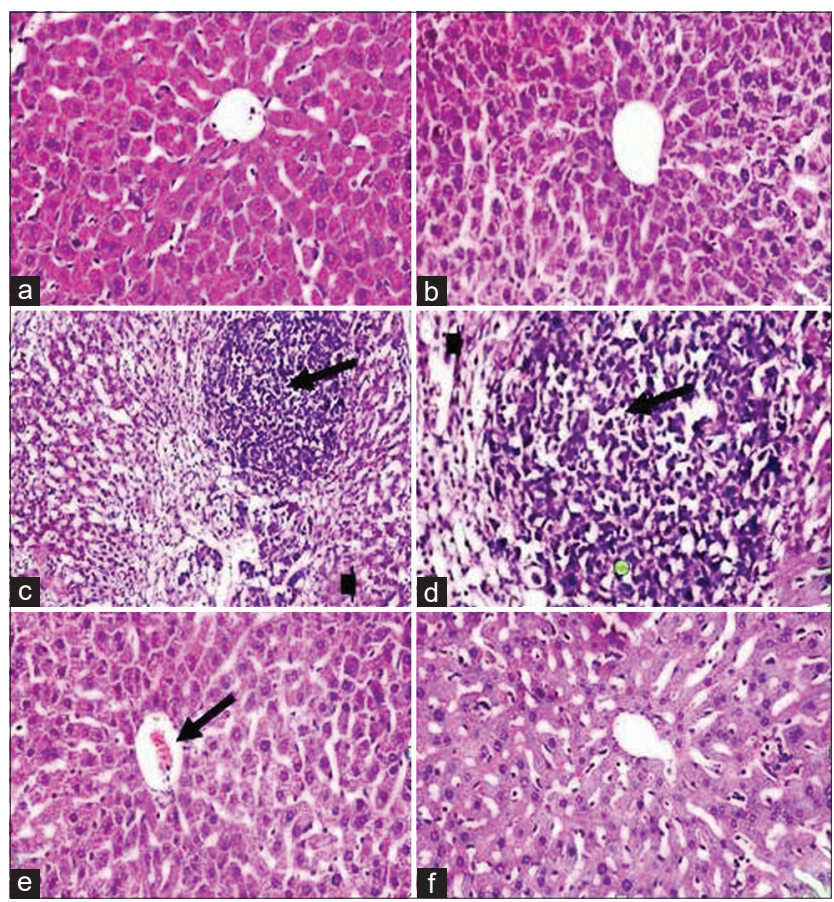

Figure-7: Photomicrograph of mice liver from Groups 1 and 2 ( $a$ and $b$ ) showing normal histological appearance of liver including central vein, blood sinusoids, hepatic cells, and Kupffer cells. Histological structure of mice liver from Group 3 ( $c$ and d) showing enlarged and congested central vein, degenerated hepatocytes (arrow head), infiltration of tumor cells, and leukocytes (arrow). Liver of mice from Group 4 (e) showing mild congested central vein (arrow). Mice liver from Group 5 (f) showing. Nearly normal histological appearance ( $\mathrm{H}$ and $\mathrm{E}, 400 \times$ ). treated with milk fat CLA 28 days before EAC inoculation (G5) and revealed nearly normal histological lesions similar to those of the control negative group (Figure-8f).

CLA has long been widely present in various diets; it has a wide range of beneficial activities in human health due to the biological importance of its isomers [54]. Milk fat is the richest natural source of CLA with concentrations typically ranging between 4 and $5 \mathrm{mg} / \mathrm{g}$ fat [55]; in this study, we could obtain milk fat contain $20 \mathrm{mg} / \mathrm{g}$ fat. Consumption of foods naturally enriched with CLA during lifetime, can reduce the risk of several diseases. Such positive effects include anticarcinogenic, antiatherogenic, antidiabetic, antiobesity, and enhancement of immune system [18]. The effects seem to be mediated primarily by two CLA isomers: c9, t11 and t10, c12 but the impact may differ depending on the isomer [56]. The obtained results in this study agrees with the most human studies that reported no significant changes in liver functions, morphology, or signs of hepatic lipodystrophy after CLA administration [15]. Milk fat CLA has been shown in vivo (TTM) reduction in tumor growth; in accord with Field and Schley [57] who justified the reduction in tumor growth by slowing cell replication, cell death through apoptosis or both. Islam et al. [58] mentioned that apoptosis is one of the most common mechanisms of the anticarcinogenic CLA isomers in animal and human cancer cells, which is mediated by dysfunction of mitochondria.

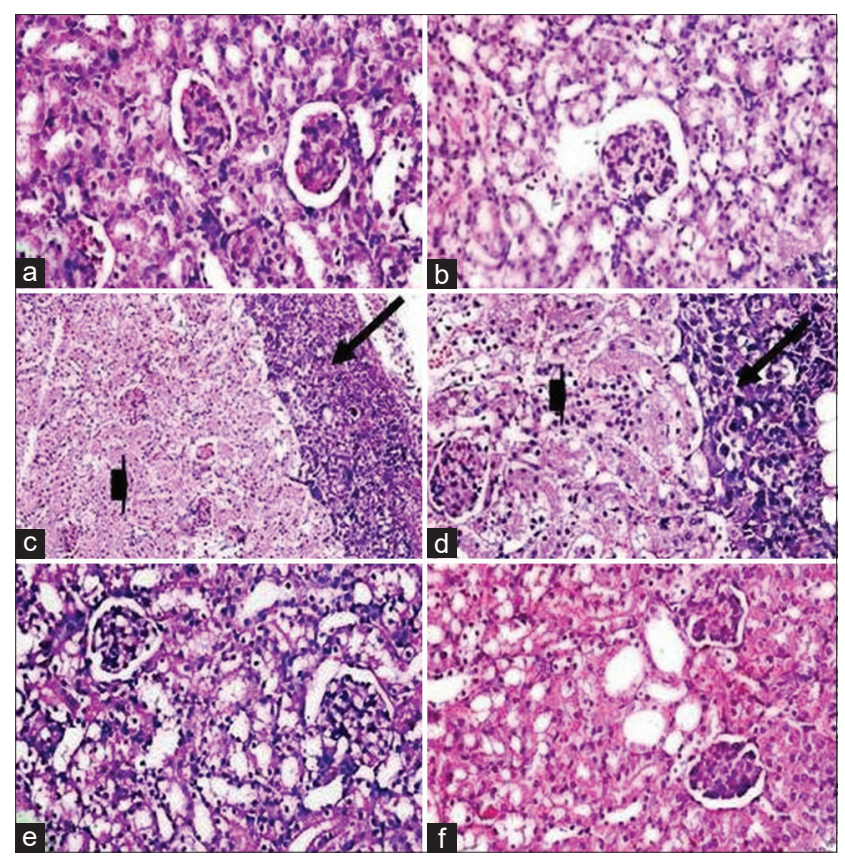

Figure-8: Photomicrograph of mice kidneys from Groups 1 and 2 ( $a$ and $b$ ) showing normal glomeruli and normal renal tubules. Histological structure of mice kidneys from Group 3 ( $c$ and $d$ ) showing glomerular atrophy and degenerated renal tubules (arrow head), proteinous casts in the lumen of renal tubules, and infiltration of tumor cells and leukocytes (arrow). Kidneys of mice from Group 4 (e) showing mildly degenerated renal tubules. Mice kidneys from Group 5 (f) showing nearly normal glomeruli and renal tubules, $(H$ and $E, 400 \times)$. 
They added that isomers of CLA induce cytotoxicity in cancer cells without significantly affecting the normal cells.

The obtained decline in ascitic fluid volume in CLA treated mice is due to significant inhibition of cell proliferation (Figure-2b) and to enhance apoptosis in EAC cells, agrees with the result obtained by Dinicola et al. [59]. Ding and Nguyen [60] confirmed that antiproliferative activity of CLA isomers is dependent on cancer cells through suppression of the gap junctional intercellular communication (GJIC), which connect the cytoplasm of neighboring cells to maintain tissue homeostasis through allowing the passage of small cytoplasmic molecules and ions, and regulate cell proliferation and apoptosis. McLachlan et al. [61] explained that deficiencies in connexin genes $(\mathrm{Cx})$, proteins, especially $\mathrm{Cx} 43$ which present in human breast tissue and most of body cells, act as a cancer marker. They added that, in cancer cells CLA isomers can enhance GJIC by inducing Cx43 gene expression, and this is an indication of its anticancer action; according to several studies $[62,63]$ confirmed that enhancing GJIC through $\mathrm{Cx} 43$ upregulation in tumor cells is positively correlated with anticancer activities. Rakib et al. [64] also demonstrated the downregulation inhibition of GJIC in human MCF-10A cells by CLA isomers which protect the phosphorylation of $\mathrm{Cx} 43$ and maintain GJIC. Song et al. [65] in another study reported that apoptosis in cancer cells (MCF-7) was associated with upregulation of GJIC through $\mathrm{Cx} 43$ expression mediated by inactivation of the activity of the nuclear factor- $\kappa \mathrm{B}$ activity.

Low concentrations of estrogen can downregulate $\mathrm{Cx} 43$ expression and lead to instability of the $\mathrm{Cx} 43$ protein in many cancer cells. CLA display the estrogen antagonistic activities through the inhibition of the ER $\alpha$-mediated signaling in ER-positive MCF-7 human breast cancer cells; unlike MCF-7 cells, the inhibitory effects of CLA on cell growth were weak or lost in ER-negative MDA-MB-231 breast cancer cells. Furthermore, CLA triggers ER $\alpha /$ protein phosphatase 2 (PP2A) complex formation and increase PP2A activity, and this explains the decreased ER $\alpha$ ERE binding activity by CLA supplementation [23]. Hence, Amaru et al. [24] proved that CLA effectively reduces breast cancer risk by inhibiting breast tumor initiation, promotion, and progression.

Our present study showed strong anticancer activity and confirmed several studies obtained similar results after treatment with CLA. There is a significant interest for using milk fat CLA as an adjuvant agent in combination with chemotherapy drugs.

\section{Conclusion}

In the light of the above observations, it can be concluded that these novel results in vivo studies indicate the significant promising anticancer activity of milk fat CLA which may be due to the additive and synergistic activity of its natural isomers. The activity was confirmed by significant improvement of MST and decrease of WBC count. On the other hand, milk fat CLA can also be used as adjuvant therapy in combination with the existing anticancer drugs. Further investigation to learn more about the mechanism of this antitumor activity are needed so that it can be formulated and be tried clinically.

\section{Authors' Contributions}

AMA: Conceptualized and designed the research. AhMA, DGA, SSA, and MHB: Participated in material preparation. AMA, DGA, and AhMA: Designed the in vivo experiment. DGA and SAA: Performed the hematological profile. AhMA, and MAA: performed the biochemical analysis. SSA performed the histopathology. SAA and MHB: Contributed in coordinating the data collections. AMA, DGA, AhMA, and SAA: Wrote the first draft of the manuscript. GE and AAM: Criticized and revised the text according to its scientific content. DGA: Conducted the statistical analysis of results, revised, and finalized the manuscript for submission. RAA: Performed editing and proofreading of the manuscript. All authors read and approved the final version of the manuscript.

\section{Acknowledgments}

The authors are thankful to the Scientific Research Project Coordination Unit of Cairo University, Egypt, for providing financial support for the 2017/2020 fiscal years. We would also like to thank President of Cairo University, Dean of Faculty of Agriculture and Laboratories of Faculty of Veterinary Medicine for providing the infrastructure for conducting this study. The gratitude also is delivered to Dr. Ahmed Gehad, Brigham Women's Hospital, Boston-MA, USA, for English editing.

\section{Competing Interests}

The authors declare that they have no competing interests.

\section{Publisher's Note}

Veterinary World remains neutral with regard to jurisdictional claims in published institutional affiliation.

\section{References}

1. Meera, R. and Chidambaranathan, N. (2017) Anticancer activity of ethanolic extract of Crataeva maqua Lour (DC) against EAC cell lines in mice. J. Pharm. Sci. Res., 9(10): 1869-1873.

2. Babasaheb, P.B., Shrikant, S.G., Ragini, G.B., Jalinder, V.T. and Chandrahas, N.K. (2010) Synthesis and biological evaluation of simple methoxylated chalcones as anticancer, anti-inflammatory and antioxidant agents. Bioorg. Med. Chem., 18(3): 1364-1370.

3. World Health Organization. (2018) Cancer. Fact sheets, 12 September 2018. https://www.who.int/news-room/factsheets/detail/cancer. Retrieved on 07-03-2021.

4. Burney, I.A., Furrukh, M. and Al-Moundhri, M.S. (2014) What are our options in the fight against breast cancer? Sultan Qaboos Univ. Med. J., 14(2): e149-51. 
5. Samiron, S., Sohel, R., Shakila, R., Mahmudul, H., Sadiur, R.S., Atikullah, S.M., Mushiur, R., Tanjir, I.H., Ikramul, K., Protic, J., Niaz, M., Shovon, A. and Arman, A. (2018) Evaluation of anticancer properties against ehrlich ascites carcinoma (EAC) cell line, cytotoxic and analgesic activity of methanol extract of Hibiscus moscheutos in Swiss Albino mice. Int. J. Pharm. Sci. Rev., Res., 49(2): 128-132.

6. Moorthi, C., Manavalan, R. and Kathiresan, K. (2011) Nanotherapeutics to overcome conventional cancer chemotherapy limitations. J. Pharm. Pharm. Sci., 14(1): 67-77.

7. Kaur, R., Kapoor, K. and Kaur, H. (2011) Plants as a source of anticancer agents. J. Nat. Prod. Plant Resour., 1(1): $119-124$

8. Arab, A., Akbarian, S.A., Ghiyasvand, R. and Miraghajani, M. (2016) The effects of conjugated linoleic acids on breast cancer: A systematic review. Adv. Biomed. Res., 5(1): 1-7.

9. Huang, S.S., Chiu, C.S., Lin, T.H., Lee, M.M., Lee, C.Y., Chang, S.J., Hou, W.C., Huang, G.J. and Deng, J.S. (2013) Antioxidant and anti-inflammatory activities of aqueous extract of Centipeda minima. J. Ethnopharmacol., 147(2): 395-405.

10. Mills, S., Ross, R.P., Hill, C., Fitzgerald, G.F. and Stanton, C. (2011) Milk intelligence: Mining milk for bioactive substances associated with human health. Int. Dairy J., 21(6): 377-401.

11. Ozaslan, M., Karagoz, I.D., Kilic, I.H. and Muhammed, E.G. (2011) Ehrlich ascites carcinoma. Afr. J. Biotechnol., 10(13): 2375-2378.

12. Kabel, A.M., Abdel-Rahman, M.N., El-Sisi, A.E.D, Haleem, M.S., Ezzat, N.M. and El Rashidy, M.A. (2013) Effect of atorvastatin and methotrexate on solid Ehrlich tumor. Eur. J. Pharmacol., 713(1-3): 47-53.

13. Badr, M.O., Edrees, N.M., Abdalla, A.A., Nasr El-Deen, A.M.N., Neamat-Alla, A.N.F. and Ismail, H.T. (2011) Anti-tumor effects of Egyptian propolis on Ehrlich ascites carcinoma. Vet. Ital., 47(3): 341-350.

14. Yuan, G.F., Chen, X.E. and Li, D. (2014) Conjugated linoleic acids and their bioactivities: A review. Food Funct., 5(7): 1360-1368.

15. Dilzer, A. and Park, Y. (2012) Implication of conjugated linoleic acid (CLA) in human health. Crit. Rev. Food Sci. Nutr., 52(6): 488-513.

16. Martínez-Monteagudo, S.I. and Saldaña, M.D.A. (2015) Retention of bioactive lipids in heated milk: Experimental and modelling. Food Bioprod. Process., 94(April 2015): 290-296.

17. Gorissen, L., Leroy, F., De Vuyst, L., De Smet, S. and Raes, K. (2015) Bacterial production of conjugated linoleic and linolenic acid in foods: A technological challenge. Crit. Rev. Food Sci. Nutr., 55(11): 1561-1574.

18. Chen, S.C., Lin, Y.H., Huang, H.P., Hsu, W.L., Houng, J.Y. and Huang, C.K. (2012) Effect of conjugated linoleic acid supplementation on weight loss and body fat composition in a Chinese population. Nutrition, 28(5): 559-565.

19. Al-Safi, Z.A. and Santoro, N. (2014) Menopausal hormone therapy and menopausal symptoms. Fertil. Steril., 101(4): 905-915.

20. Rozenberg, S., Vandromme, J. and Antoine, C. (2013) Postmenopausal hormone therapy: Risks and benefits. Nat. Rev. Endocrinol., 9(4): 216-227.

21. Munsell, M.F., Sprague, B.L., Berry, D.A., Chisholm, G. and Trentham-Dietz, A. (2014) Body mass index and breast cancer risk according to postmenopausal estrogen-progestin use and hormone receptor status. Epidemiol. Rev., 36(1): 114-136.

22. Wang, J., Liu, X., Zhang, X., Liu, J., Ye, S., Xiao, S., Chen, H. and Wang, H. (2013) Induction of apoptosis by c9, t11-CLA in human endometrial cancer RL 95-2 cells via ERalpha-mediated pathway. Chem. Phys. Lipids, 175-176(October-November 2013): 27-32.
23. Bocca, C., Bozzo, F., Cannito, S., Colombatto, S. and Miglietta, A. (2010) CLA reduces breast cancer cell growth and invasion through ERalpha and PI3K/Akt pathways. Chem. Biol. Interact., 183(1): 187-193.

24. Amaru, D.L., Biondo, P.D. and Field, C.J. (2010) The role of conjugated linoleic acid in breast cancer growth and development. Open Nutraceuticals J., 3(1): 30-46.

25. Benjamin, S., Prakasan, P., Sreedharan, S., Andre-Denis, G. Wright, A.G. and Spener, F. (2015) Pros and cons of CLA consumption: An insight from clinical evidences. Nutr. Metab., 12(4): 1-20.

26. Zahan, R., Alam, M.B., Islam, M.S., Sarker, G.C., Chowdhury, N.C., Hosain S.B., Mosaddik, M.A., Jesmin, M. and Haque, M.E. (2011) Activity of Alangium salvifolium flower in ehrlich ascites carcinoma bearing mice. Int. J. Cancer Res., 7(3): 254-262.

27. Samudrala, P.K., Augustine, B.B., Kasala, E.R., Bodduluru, L.N., Barua, C. and Lahkar, M. (2015) Evaluation of antitumor activity and antioxidant status of Alternanthera brasiliana against Ehrlich ascites carcinoma in Swiss albino mice. Pharmacogn. Res., 7(1): 66-73.

28. Abu Osman, M., Rashid, M.M., Abdul Aziz, M., Habib, M.R. and Karim, M.R. (2011) Inhibition of Ehrlich ascites carcinoma by Manilkara zapota L. stem bark in Swiss albino mice. Asian Pac. J. Trop. Biomed., 1(6): 448-451.

29. García-Moreno, E., Tomás, A., Atrián-Blasco, E., Gascón, S., Romanos, E., Rodriguez-Yoldi, M., Cerradaa, E. and Laguna, M. (2016) In vitro and in vivo evaluation of organometallic gold(I) derivatives as anticancer agents. Dalton Trans., 45(6): 2462-2475.

30. Sangameswaran, B., Pawar, S.P., Saluja, M.S. and Sharma, A. (2012) Antitumor activity of Sida veronicaefolia against Ehrlich ascites carcinoma in mice. J. Pharm. Res., 5(1): 315-319.

31. Fernands, D.P., Pimentel, M.L., Do Santos, F.A., Praxedes, E.A., De Brito, P.D., Lima, M.A., Lelis, I.C., De Macedo, M.F. and Bezerra, M.B. (2018) Hematological and biochemical profile of BALB/c nude and C57BL/6 SCID female mice after ovarian xenograft. An. Acad. Bras. Cienc., 90(4): 3941-3948.

32. Santos, E.W., Oliveira, D.C., Hastreiter, A., Silva, G.B., Beltran, J.S., Tsujita, M, Crisma, A.R., Neves, S.M., Fock, R.A. and Borelli, P. (2016) Hematological and biochemical reference values for C57BL/6, Swiss Webster and BALB/c mice. Braz. J. Vet. Res. Anim. Sci., 53(2): 138-145.

33. Nader, F., Hanyath, A.R. and Wittwer, C.T. (2018) Tietz Fundamentals of Clinical Chemistry and Molecular Diagnostics. $8^{\text {th }}$ ed. Saunders, United States.

34. Moreira, V.G., Vaktangova, N.B., Gago, M.M., Gonzalez, B.L., Alonso, S.G. and Rodriguez, E.F. (2018) Overestimation of albumin measured by bromocresol green vs bromocresol purple method: Influence of acute-phase globulins. Lab. Med., 49(4): 355-361.

35. Lalithadevi, B., Muthiah, N.S. and Murty, K.S.N. (2018) Antioxidant activity of conjugated linoleic acid. Asian J. Pharm. Clin. Res., 11(11): 169-173.

36. Bancroft, J.D., Suvarna, K. and Layton, C. (2012) Bancroft's Theory and Practice of Histological Techniques. $7^{\text {th }}$ ed. Churchill Livingstone, London, United Kingdom.

37. Jemal, A., Bray F., Center M.M., Ferlay J. and Ward E., (2011) Global cancer statistics. CA Cancer J.Clin., 61(2): 69-90.

38. Reddy, V.N., Nagarathna, P.K.M. and Divya, M. (2013) Evaluation of anti-cancer activity of Ruellia tuberosa on EAC induced mammary tumor. Int. J. Pharmacol. Toxicol., 1(2): $36-42$.

39. Patra, S., Muthuraman, M.S., Prabhu, A.R., Priyadharshini, R.R. and Parthiban, S. (2015) Evaluation of antitumor and antioxidant activity of Sargassum tenerrimum against Ehrlich ascites carcinoma in mice. Asian Pac. J. Cancer Prev., 16(3): 915-921. 
40. Hashem, M.A., Mahmoud, E.A. and Abd-Allah, N.A. (2020) Alterations in hematological and biochemical parameters and DNA status in mice bearing Ehrlich ascites carcinoma cells and treated with cisplatin and cyclophosphamide. Compar. Clin. Pathol., 29(2020): 517-524.

41. Etim, E.A., Adebayo, Y.A. and Ifeanyi, O.E. (2018) Effect of Luffa cylindrica leaf extract on hematological parameters of Swiss Albino mice. Med. Aromat. Plants, 7(2): 1-5.

42. Dolai, N., Karmakar, I., Kumar, R.B.S., Kar, B., Bala, A. and Haldar, P.K. (2012) Evaluation of antitumor activity and in vivo antioxidant status of Anthocephalus cadamba on Ehrlich ascites carcinoma treated mice. J. Ethnopharmacol., 142(3): 865-870.

43. Halaby, M.S., Farag, M.H. and Mahmoud, S.A.A. (2015) Protective and curative effect of garden cress seeds on acute renal failure in male albino rats. Middle East J. Appl. Sci.., 5(2): 573-586.

44. Habib, M.R., Aziz, M.A. and Karim, M.R. (2010) Inhibition of Ehrlich's ascites carcinoma by ethyl acetate extract from the flower of Calotropis gigantea L. in mice. J. Appl. Biomed., 8(1): 47-54.

45. Al Abdan, M. (2012) Alfa-lipoic acid controls tumor growth and modulates hepatic redox state in ehrlich-ascites-carcinoma-bearing mice. Sci. World J., 2012 (509838): 1-6.

46. Saad, E.A., Hassanien, M.M., El-mezayen, H.A. and ELmenawy, N.M. (2017) Regression of murine Ehrlich ascites carcinoma using synthesized cobalt complex. Med. Chem. Commun., 2017(8): 1103-1111.

47. Abd El-Gawad, A.M., Aboul-Enein, A.M., Ali R.A., Abo El-Hassan, D.G. and Bakr M.H. (2020) The Anticancer Activity of Milk Rich in Conjugated Linoleic Acid, CLA (Under Publication).

48. Ali, D.A., Badr, N.K. and Abou-El-Magd, R.F. (2015) Antioxidant and hepatoprotective activities of grape seeds and skin against Ehrlich solid tumor induced oxidative stress in mice. Egypt. J. Basic Appl. Sci., 2(2): 98-109.

49. Das, U.N. and Madhavi, N. (2011) Effect of polyunsaturated fatty acids on drug-sensitive and resistant tumor cells in vitro. Lipids Health Dis., 10(159): 1-35.

50. Das, U.N. (2020) Immune system, inflammation, and essential fatty acids and their metabolites in cancer. In: Molecular Biochemical Aspects of Cancer. Humana, New York, p67-157.

51. Abou Zaid, O.A.R., Hassanein, M.R.R., El-Senosi, Y.A. and El-Shiekha, M.F. (2011) Ameliorative effect of curcumin and tannic acid on tumor-induced in female mice. Benha Vet. Med. J., 2011(1): 61-69.

52. Bhattacharyya, A., Mandal, D., Lahiry, L., Bhattacharyya, S., Chattopadhyay, S., Ghosh, U.K., Sa, G. and Das, T. (2007) Black tea-induced amelioration of hepatic oxidative stress through antioxidative activity in EAC-bearing mice. $J$. Environ. Pathol. Toxicol. Oncol., 26(4): 245-254.

53. Abd El-Wahab, S.M. and Fouda, F.M. (2009) Histological and histochemical study on the effect of Ehrlich ascites carcinoma on the liver and kidney of mice and the possible protective role of tetrodotoxin. Egypt. J. Biol., 11(2009): 13-25.
54. Rishehri, S.M.D., Rahbar, A.R. and Ostovar, A. (2019) Effects of conjugated linoleic acid intake in the form of dietary supplement or enriched food on c-reactive protein and lipoprotein (a) levels in humans: A literature review and meta-analysis. Iran. J. Med. Sci., 44(5): 359-373.

55. Marín, M.P., Meléndez, P.G., Aranda, P. and Ríos, C. (2018) Conjugated linoleic acid content and fatty acids profile of milk from grazing dairy cows in southern Chile fed varying amounts of concentrate. J. Appl. Anim. Res., 46(1): 150-154.

56. Korhonen, H.J. (2011) Bioactive milk proteins, peptides and lipids and other functional components derived from milk and bovine colostrum. In: Functional Foods. $2^{\text {nd }}$ ed., Ch. 20. Woodhead Publishing, Cambridge, UK.

57. Field, C.J. and Schley, P.D. (2004) Evidence for potential mechanisms for the effect of conjugated linoleic acid on tumor metabolism and immune function. Am. J. Clin. Nutr., 79(6): 1190S-1198S

58. Islam, M.A., Kim, Y.S., Oh, T.W., Kim, G.S., Won, C.K., Hoon, G., Kim, H.G., Choi, M.S., Kim, J.O. and Ha, Y.L. (2010) Superior anticarcinogenic activity of trans, trans-conjugated linoleic acid in Nmethyl-N-nitrosoureainduced rat mammary tumorigenesis. J. Agric. Food Chem., 58(9): 5670-5678.

59. Dinicola, S., Cucina, A., Pasqualato, A., Proietti, S. and D'Anselmi, F. (2010) Apoptosis-inducing factor and caspase-dependent apoptotic pathways triggered by different grape seed extracts on human colon cancer cell line Caco-2. Br. J. Nutr., 104(6): 824-832.

60. Ding, Y. and Nguyen, T.A. (2012) Gap junction enhancer potentiates cytotoxicity of cisplatin in breast cancer cells. $J$. Cancer Sci. Ther., 4(11): 371-378.

61. McLachlan, E., Shao, Q. and Laird, D.W. (2007) Connexins and gap junctions in mammary gland development and breast cancer progression. J. Membr. Biol., 218(1-3): 107-121.

62. Zahran, M., Aboul-Enein, A. and Aboll-Ella, F. (2005) Molecular changes on cancer cells as affected by willow extracts. Res. J. Agric. Biol. Sci., 1(3): 284-287.

63. Tishchenko, A., Azorín, D.D., Vidal-Brime, L., Muñoz, M.J., Arenas, P.J., Pearce, C., Girao, H., Ramón, Y., Cajal, S. and Aasen, T. (2020) Cx43 and associated cell signaling pathways regulate tunneling nanotubes in breast cancer cells. Cancers, 12(10): 2798.

64. Rakib, M.A., Kim, Y.S., Jang, W.J., Jang, J.S., Kang, S.J. and Ha, Y.L. (2011) Preventive effect of t,t-conjugated linoleic acid on 12-O- tetradecanoylphorbol-13-acetate-induced inhibition of gap junctional intercellular communication in human mammary epithelial MCF-10A cells. $J$. Agric. Food Chem., 59(8): 4164-4170.

65. Song, H.J., Sneddon, A.A., Heys, S.D. and Wahle, K.W.J. (2006) Induction of apoptosis and inhibition of NF- $\kappa$ B activation in human prostate cancer cells by the cis- 9 , trans- 11 but not the trans-10, cis-12 isomer of conjugated linoleic acid. Prostate, 66(8): 839-846. 